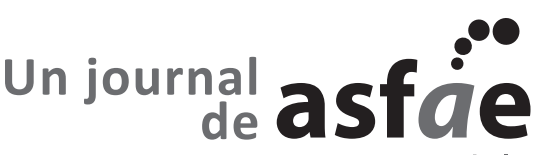 \\ chile
}

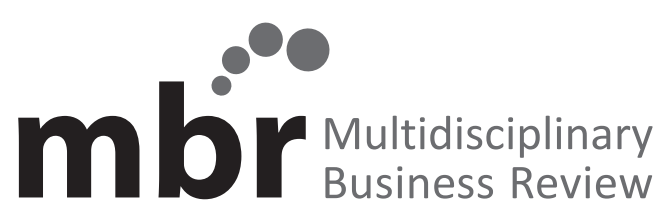

\section{FOSTERING ECONOMIC GROWTH IN FRONTIER MARKETS: PERCEPTIONS IN THE TUNISIAN POST-ARAB SPRING}

\author{
FOMENTO DEL CRECIMIENTO ECONÓMICO EN LOS MERCADOS FRONTERIZOS: \\ PERCEPCIONES DESPUÉS DE LA PRIMAVERA ÁRABE EN TÚNEZ
}

\author{
Victoria L. Crittenden ${ }^{\mathrm{a}}$ Miranda Beggin ${ }^{\mathrm{b}} \bullet$ William F. Crittenden ${ }^{\mathrm{c}} \bullet$ Kaylea Dohm $^{\mathrm{d}}$ \\ Classification: Empirical paper - research \\ Received: June 1, 2020 / Revised: July 27, 2020 / Accepted: August 17, 2020
}

\begin{abstract}
The need for economic reform is at the heart of the criticism for many frontier economies. Fostering entrepreneurship and identifying business opportunities generate paths for job creation and economic growth. Given the underlying tensions that led to the Arab Spring, our study focuses on the one country that is considered to be a post-Arab Spring success story and explores the Small-Medium Enterprise (SME) business environment in Tunisia. Perceived changes in the SME environment in Tunisia were examined qualitatively via in-depth personal interviews with 21 Tunisian economic experts. Analysis of the interview data followed the thematic analysis approach. Our findings indicate that social reforms and the development of financing alternatives should be paramount for the growth of SMEs and the economic success of frontier markets. Additionally, educational reform and communication to foster entrepreneurial behaviour and effective managerial practices are required to ensure that current and future generations are prepared to engage successfully in the formal economy. Although our research focused on a single frontier market economy, we believe these findings are generalizable to many emerging economies. The findings should hold considerable policy implications due to the nature of the reforms suggested. There are popular and business press articles about the post-Arab Spring and stories about Tunisia's Jasmine Revolution; however, increased scholarly focus on entrepreneurial efforts post-Arab Spring in Tunisia will further solidify the intersection of economic gain and human development.
\end{abstract}

Keywords: Frontier markets, Small-Medium Enterprise, financing, entrepreneurship, economic growth.

\section{Resumen}

La necesidad de una reforma económica está en el centro de las críticas de muchas economías fronterizas. El fomento del espíritu empresarial y la identificación de oportunidades comerciales crean caminos para la creación de empleo y el crecimiento económico. Dadas las tensiones subyacentes que llevaron a la Primavera Árabe, nuestro estudio se centra en el país considerado como una historia de éxito posterior a la Primavera Árabe y explora el entorno empresarial de las pequeñas y medianas empresas (PYME) en Túnez. Los cambios percibidos en el entorno de las PYME en Túnez se examinaron cualitativamente mediante entrevistas personales en profundidad con 21 expertos económicos tunecinos. El análisis de los datos de la entrevista siguió el enfoque de análisis temático. Nuestros hallazgos indican que las reformas sociales y el desarrollo de alternativas de financiamiento deben ser primordiales para el crecimiento de las PYME y el éxito económico de los mercados fronterizos. Además, la reforma educativa

\footnotetext{
Babson Research Scholar, Babson College, Babson Park, MA USA. E-mail: vcrittenden@babson.edu

Third Sector, Boston, MA USA. E-mail: mbeggin94@gmail.com

D'Amore-McKim School of Business, Northeastern University, Boston, MA USA. E-mail: w.crittenden@northeastern.edu

D’Amore-McKim School of Business, Northeastern University, Boston, MA USA. E-mail: dohm.k@husky.neu.edu
} 
y la comunicación para fomentar el comportamiento empresarial y la práctica de gestión eficaz son necesarias para garantizar que las generaciones actuales y futuras estén preparadas para participar con éxito en la economía formal. Aunque nuestra investigación se centró en una economía de mercado de frontera única, creemos que estos hallazgos se pueden generalizar a muchas economías emergentes. Los hallazgos deberían tener considerables implicaciones políticas debido a la naturaleza de las reformas sugeridas. Hay artículos de prensa popular y de negocios sobre la post Primavera Árabe e historias sobre la Revolución Jazmín en Túnez; sin embargo, un mayor enfoque académico en los esfuerzos empresariales posteriores a la Primavera Árabe en Túnez solidificará aún más la intersección de la ganancia económica y el desarrollo humano.

Palabras clave: mercados fronterizos, pequeña y mediana empresa, financiamiento, emprendimiento, crecimiento económico.

\section{Introduction}

Domestic credit conditions in emerging economies and, thus, the development of the countries globally are dependent upon both local financial systems and the flow of capital from external sources (Lotto, 2017). However, Osafo-Kwaako, Singer, White \& Zouaoui (2018) noted that most people and small businesses in emerging economies do not participate fully in the formal financial system. According to their statistics, two billion individuals and 200 million small business in these emerging economies lack access to formal savings and credit. Given that access to capital is a critical factor in stimulating business formation and growth, potentially dynamic and growing parts of a nation's economy struggle to survive due to insufficient capital and liquidity problems (Coleman \& Carsky, 1999). According to Geller (2017), even though entrepreneurship in emerging markets is prevalent in the form of small business ownership, its contribution to economic growth is limited due to the lack of funding.

Credit accessibility was a contributing factor to the Arab Spring and the movements that followed. The absence of liquidity in the markets and fund availability, in conjunction with corruption and structural inefficiencies, fed a climate in which unemployment, instability, and frustration grew. The current research focuses specifically on perceived changes in the small business environment, the culture of entrepreneurship, the ease of small business incorporation, and entrepreneurship education in the post-Arab Spring, using the post-Arab Spring as the point of a possible shift in the overall business environment and the growth of the entrepreneurship ecosystem in emerging markets.

The current paper is organized as follows. In the next section, frontier markets, as a subset of the emerging markets, are introduced and entrepreneurship and SmallMedium Enterprise (SME) development are discussed. An overview of Tunisia, the sole success story from the Arab Spring, is then provided. The introduction to Tunisia sets the stage for the interview process in which
21 experts in Tunisia provided input with regard to their perceptions of entrepreneurship and SME success post-Arab Spring. Findings from these interviews, as derived via thematic analysis, are elaborated specifically for Tunisia. The paper concludes with thematic results offering insights across frontier and emerging markets.

\section{Emerging Economies}

Researchers and practitioners have sought to identify and understand low income, rapid growth countries that are using economic liberalization as the primary engine of growth (Crittenden \& Crittenden, 2012). These emerging economies unfolded initially with the BRIC countries: Brazil, Russia, India, and China. Later, South Africa became an emerging market, resulting in BRICS. The 'Next Eleven' (i.e., Bangladesh, Egypt, Indonesia, Iran, Mexico, Nigeria, Pakistan, the Philippines, South Korea, Turkey, and Vietnam) joined the BRICS, encompassing a wide range of nations of potentially regional powerhouses transitioning through turbulent environments of economic, social, and political reforms (Crittenden \& Crittenden, 2015).

Crittenden and Crittenden (2010) explored emerging economies and suggested a continuum of market economies, with a lack of demarcation between emerging and developed markets. Minović \& Živković (2010) divided the continuum into three major types: (1) developed markets in North America, Western Europe, and Japan, (2) emerging markets of East Asia and Latin America, and (3) frontier markets of Southeast Asia and South-eastern Europe. With investors increasingly more comfortable doing business in remote locations of the world, Levisohn (2013) noted the importance of frontier markets for the future of economic growth.

\section{Frontier Markets}

Frontier markets began presenting attractive investment opportunities around the turn of the $21^{\text {st }}$ century, 
yet research into these markets is scarce (Stereńczak, Zaremba, \& Umar, 2020). Table 1 shows the frontier market classification offered by Frontier Market News. Shoenholz (2011) suggested that a major attraction of frontier markets is the lack of correlation to each other, which is evident in the coverage across the five geographic groupings, and McCormick (2013) went so far as to suggest that frontier markets are tomorrow's emerging markets.

Carpenter (2020) contrasted emerging and frontier markets by suggesting that frontier economies include those countries that are in the earliest stages of political and economic development. Frontier markets are more developed than lesser-developed countries, but they are less developed and more illiquid than emerging economies (Frontier Market News, 2020). Additionally, frontier markets are assumed less efficient than emerging markets, due largely to lower levels of access to market depth and trade-reporting information (Gupta, 2011). Mohti (2019) noted that frontier markets are in countries that are often poor, politically mismanaged, and economically fragile. Within these frontier markets, a recommendation for improving employment and the economy is entrepreneurship (Bishai \& Mastic, 2016).

Table 1. Frontier Economies

\begin{tabular}{|c|c|c|c|c|}
\hline & Europe & & Middle & \\
\hline Americas & \& CIS & Africa & East & Asia \\
\hline Argentina & Bosnia \& & Benin & Bahrain & Bangladesh \\
\hline Jamaica & Herzegovina & Botswana & Jordan & Kazakhstan \\
\hline Panama & Bulgaria & Burkina Faso & Kuwait & Palestine \\
\hline Trinidad \& & Croatia & Côte d'Ivoire & Lebanon & Sri Lanka \\
\hline \multirow[t]{14}{*}{ Tobago } & Cyprus & Ghana & Oman & Vietnam \\
\hline & Estonia & Guinea-Bissau & & \\
\hline & Iceland & Kenya & & \\
\hline & Latvia & Mali & & \\
\hline & Lithuania & Mauritius & & \\
\hline & Macedonia & Morocco & & \\
\hline & Malta & Niger & & \\
\hline & Romania & Nigeria & & \\
\hline & Serbia & Senegal & & \\
\hline & Slovakia & Tanzania & & \\
\hline & Slovenia & Togo & & \\
\hline & Ukraine & Tunisia & & \\
\hline & & Zambia & & \\
\hline & & Zimbabwe & & \\
\hline
\end{tabular}

Source: Frontier Market News, 2020.

\section{Entrepreneurship (SMEs) in Frontier Markets}

According to Sidrat, Amouri, Boujelbene \& Boudabbous (2016, p. 60), "entrepreneurship is considered as a dynamic process of creating wealth through innovation and a process of conceptualizing, organizing, launching and nurturing a business opportunity into a potentially high growth venture in a complex and unstable environment." Thus, SMEs are the backbone of every economy across the globe (Eggers, 2020), and SMEs are receiving increased attention in frontier markets largely due to being the main driver of job creation and, thus, economic growth (Birch, 1987; García-Quevedo, Pellegrino, \& Vivarelli, 2014; Pellegrino, Piva, \& Vivarelli, 2012; Schneider \& Veugelers, 2010).

While each country has its own definition of SME size, the generally accepted definition is that small enterprises have fewer than 50 employees and medium enterprises have between 50 and 250 employees (Liberto, 2019). Additionally, microenterprises have become commonplace, and these companies have fewer than 10 employees (Liberto, 2019). According to Beck (2013), $95 \%$ of companies globally fall into the microenterprise or SME categories, with $50 \%$ of employees in low and lower-middle income countries working in companies with fewer than 100 employees. As noted by Hallberg (2000, p. 5), "microenterprises and SMEs are the emerging private sector in poor countries, and thus form the base for private sector-led growth." Women-owned SMEs were noted as growing faster than the economy in several Organisation for Economic Co-operation and Development (OCED) countries, although there was concern that the economic potential of women entrepreneurs is not being met (OCED, n.d.).

In a comprehensive report offered by the OCED (n.d.), several problems confronted by SMEs were outlined, as were several policy tools for enhancing SME survival rates. The main barriers identified by the OCED were capital markets (financing), government regulations, indirect labour costs, access to foreign markets, and difficulties in recruiting qualified staff and skilled workers. In terms of financing, the OCED suggested that SMEs are confronted with higher interest rates while also faced with credit rationing because of a shortage of collateral. Additionally, SMEs have difficulty with the regulatory environment since management is likely ill equipped to understand compliance procedures given the cost of a highly skilled workforce. Without financing and a highly skilled workforce to create and implement strategy, it is unlikely that an SME can compete with, or have access to, foreign markets. To this end, the OCED and others (e.g., Cravo, 2010; Hussain, Farooq, \& 
Akhtar, 2012) have argued for institutional policies that assist SMEs in creating and ensuring value to the companies and societies as a whole.

\section{Tunisia: The Arab Spring Success Story}

Arouri, Ben Youssef, Quatraro \& Vivarelli (2018) offered a brief history of Tunisia leading up to the Arab Spring. Charting the country's course, the authors noted the following:

1. the diverse political, social, and economic phases inherent in the country's independence in the late 1950s/early 1960s,

2. a change of course in the 1970 s that featured import substitution and export promotion,

3. a slowdown in productivity growth due to economic mismanagement and political instability in the 1980 s,

4. the liberalization policies in the 1990s that encouraged foreign investments and integration in European markets, and

5. a marked GDP growth in the 2000s.

However, the country entered into the $21^{\text {st }}$ century with an uneven distribution of wealth that led to social conflicts and youth unemployment (Arouri et al., 2018).

In 2010 and 2011, pro-democracy protests and uprisings occurred in the Middle East and North Africa (MENA). Referred to as the Arab Spring, the uprisings began in Tunisia (referred to as Tunisia's "Jasmine Revolution") and ultimately challenged the authoritarian regimes in the largely Muslim countries of Tunisia, Morocco, Syria, Libya, Egypt, and Bahrain. Economic grievances were at the heart of the uprisings, with challenges such as high unemployment, corruption, lack of governmental accountability and transparency, and lack of support for the development of small enterprises (O’Sullivan, Rey, \& Mendez, 2011). Unfortunately, while registering one of the highest new firm entry rates in the MENA region, Tunisia was registering only one entry per 1,000 people of working age in 2010 (O'Sullivan et al., 2011). Yet, Tunisia is the sole country to have made a long-lasting transition to democracy because of the Arab Spring (Arieff, 2019; Masoud, 2018). Statistically, however, economic growth has been slow in Tunisia since the Arab Spring, with unemployment above 15\%, inflation over $7 \%$, and public debt almost $80 \%$ of the GDP (Arieff, 2019). Almost 10 years after the country's Jasmine Revolution, close to $90 \%$ of Tunisians believed their country was going in the wrong direction, with economic and security reforms still a priority (Arieff, 2019; Bishai \& Mastic, 2016).
While support for trade is strong in the MENA region, Jamal \& Milner (2019, p. 551) referred to Tunisiaas "low skillabundant."That is, very few adultshave completed college, managerial skills are lacking, geographic mobility is limited, and Tunisian's are risk averse (Sidrat et al., 2016). All of these issues affect employability; thus, Bishai and Mastic (2016) noted that the most popular suggested economic remedy for fostering economic growth in Tunisia was the restructuring of investment laws to encourage entrepreneurship, which should lead to economic independence. Dziri (2013) reported that the "Doing Business" ranking for 2013 placed Tunisia consistently low in terms of SMEs and business creation. Five years later, Arouri et al. (2018) found that very young and small firms generated substantial employment in Tunisia and were a main driver of net job creation.

To this end, youth and entrepreneurship education research has been a priority in relation to Tunisia. Ettis \& Kefi (2016) utilized personality traits theory, postulating a relationship between personality and risk tolerance among Tunisian university students and were able to identify traits that encouraged and hindered entrepreneurial intentions. Along the same lines, Touzani, Jlassi, Maalaoui \& Bel Haj Hassine (2015) explored the motivations and inhibitions linked to the entrepreneurial act of young people in Tunisia. Gabsi (2019) reported, however, that youth in Tunisia found the Arab Spring to be a failure in socio-economic terms, although it did allow them to assert their Tunisian identity. Education wise, Alaref, Brodmann \& Premand (2019) reported that there were no sustained impacts on self-employment or employment outcomes for university students four years after graduation. This 2019 report complemented an earlier report (Premand, Brodmann, Almeida, Grun \& Barouni, 2012) that offered small, short-term impacts on self-employment and aspirations one year after university graduation.

Additionally, Beninger, Ajjan, Mostafa \& Crittenden (2016) and Crittenden, Crittenden \& Ajjan (2019) suggested that female entrepreneurship was an important engine for growth in developing economies, yet the MENA region has notoriously low business start-up rates for women entrepreneurs. Amidst these somewhat dire numbers, the legal and socioeconomic status of Tunisian women is reportedly high among Arab countries (Arieff, 2019), with women more supportive of liberal trade policy than men (Jamal \& Milner, 2019). Unfortunately, Morched \& Jarboui (2018) reported that unemployment and poverty are particularly affecting young Tunisian women.

Thus, while Tunisia is noted as the sole success story from the uprisings (Arieff, 2019; Masoud, 2018), the 
findings from scholarly research are mixed in terms of changes in the SME environment following the post-Arab Spring (Jasmine Revolution). The intent of the current research was to capture perceived changes in the SME environment across a variety of constituents in Tunisia. Thus, the attempt was to derive perceptions of changes that might have occurred after the uprisings. The attempt was not, however, to assume causation between the Arab Spring and any perceived changes in the business environment in Tunisia.

\section{Methodology}

\section{Sample and Data Collection}

Perceived changes in the SME environment in Tunisia were examined qualitatively via in-depth personal interviews with 21 Tunisian economic experts. These 21 individuals had expertise in entrepreneurship, SME development, banking, and marketplace lending as related to frontier markets and Tunisia in particular. They represented organizations such as USAID, the World Bank, the World Trade Organization, the Tunisian American Enterprise Fund, the Middle East Investment Initiative, Tunisian Investment Authority, various lending and crowdfunding platforms, large banking institutions, an international accounting firm, business leader associations, business strategy consultants, ministry departments, and higher education. Seeking input from such Tunisian experts enabled the generation of knowledge grounded in human experience.

To guide the interview process, six questions were derived from the scholarly and practice-oriented literature on the post-Arab Spring described previously (see Table 2). The interview questions flowed from the literature on the Arab Spring and its impact on the economy, in particular, job creation as a result of SME development. While general information was acquired in the interviews, the interviews followed the positivist approach with the six questions designed to elicit viewpoints on the SME environment after the Arab Spring. Additional clarification questions were asked if more detail was needed on a response or to explore a topic further. Since the purpose of the interviews was the individual perception of changes post-Arab Spring, questions about the SME environment prior to the uprising were not posed.

The in-person interviews were held in Tunisia, and, due to the necessary travel to Tunisia, one interviewer conducted all the interviews. The interviewer was an experienced traveller to the Middle East, having previously received an exchange fellowship for the National Council on US-Arab Relations. A general description
Table 2. Interview Questions

\begin{tabular}{l}
$\begin{array}{l}\text { 1. What, if any, changes in the SME environment have you noticed since } \\
\text { the Arab Spring? }\end{array}$ \\
\hline 2. How would you describe the Tunisian culture toward entrepreneurship? \\
\hline 3. Is it easy to create an SME in Tunisia? \\
\hline 4. How imperative is SME development in Tunisia? \\
\hline 5. Is there access to financing for entrepreneurs? \\
\hline 6. Do Tunisian entrepreneurs have the ability to scale their businesses?
\end{tabular}

of the research project was provided to all interviewees when the interviews were scheduled. In the personal interviews, the interviewees were once again reminded of the general research purpose and project description. All interviewees were assured of anonymity in the reporting of the results. Additionally, there were times that respondents preferred to "pass" on the query or felt they had responded to the query in a previous question since the questions were not mutually exclusive.

\section{Data Analysis}

Analysis of the interview data followed the thematic analysis approach. The six phases of thematic analysis, as suggested by Nowell, Norris, White \& Moules (2017), were adhered to as closely as possible throughout an iterative process. These six phases include: (1) familiarization with the data, (2) generating initial codes, (3) searching for themes, (4) reviewing themes, (5) defining and naming themes, and (6) producing the report.

Upon completion of the interviews, the detailed responses to the six interview questions, in addition to any other points recorded during the conversations, were compiled by the interviewer and then shared with members of the research team for purposes of familiarity (Phase 1). For Phases 2-4 of the thematic process, critical analysis of the in-depth interviews was first undertaken within the domain of each interview question. The main objective here was the recognition of recurring themes emerging in the respondents' answers to each of the questions. Additionally, if an interviewee shared one or more key insights not mentioned or alluded to by other respondents, that data was highlighted and examined independently of the emerging theme within each question. As suggested by Nowell et al. (2017), spreadsheets were compiled for tracking responses for each question and for summarizing key points. After that, per Phase 5 of the thematic approach, transcripts of the question responses were analysed to conclude with general thematic links and patterns across the six structured question responses that provide insight across frontier and emerging markets in general. These five phases involved 
much back and forth among the research team, prior to the preparation of the final data report (Phase 6).

\section{Results}

\section{Phases 2-4 Findings}

Since Tunisia is considered an Arab Spring success story, Question 1 of the interview questions queried respondents about changes they had seen since the Arab Spring. Instability in the government and corruption went hand-in-hand, with 10 of the 16 responding interviewees referring to both issues. One interviewee captured this succinctly as, "economic reform is on the back burner after social reform changes," with corruption perceived to be worsening within the country. Seven of the 16 respondents, however, saw a positive change in terms of the entrepreneurial ecosystem development in the country. A couple of people noted the establishment of incubators, and another referred to entrepreneurship plan competitions that had begun occurring. Interestingly, only one respondent viewed the negative changes (i.e., corruption and instability) simultaneously with the positive aspects of entrepreneurial growth.

With very young and small firms found to be critical for economic prosperity, yet an abysmal start-up rate in Tunisia, Question 2 concerned the perception of culture toward entrepreneurship in the country. Six of the 19 interviewees responding to the question felt there was an entrepreneurial culture in Tunisia. Twelve respondents noted problems with the educational system that were inhibiting entrepreneurial efforts. These problems included inefficient research centres, a lack of technical skills (which might tie to a concomitant low number of registered patents), a lack of training and encouragement in entrepreneurship, poor hard skill development, poor soft skill development, a lack of a global mindset, and a tendency to focus on a finding a safe work path.

The respondents were then queried about the ease of starting a SME in Question 3. The country's bureaucracy and lack of financing were noted as constraints inhibiting efforts by 19 of the 20 interviewees. In terms of the bureaucracy, one respondent noted it as the "biggest constraint," with many comments about the length of time it takes to register a business in Tunisia. Within the context of bureaucracy, the difficulty in going outside of Tunisia for business related issues was noted by several respondents, with one saying that it was impossible to get a visa to travel to some countries. Closely related to bureaucracy was the lack of financing available for would-be entrepreneurs. Banks were very conservative, yet it was not possible to work with financial institutions outside of Tunisia. Only one of the interviewees focused on the pos- itive aspects of starting a SME in Tunisia, and he did so by noting the opportunity for growth for new firms.

The respondent who presented the positive tone in the third question was also a strong voice with regards to SME development being imperative for the Tunisian economy. Only 10 of the interviewees had contributions to add for Question 4. All 10 of them were very vocal in noting that SME development is key to economic reform. There were comments about SMEs being the route for job creation and the development of women and youth and, thus, possibly the "solution to unemployment." At the same time, the significant size of the informal sector was noted, with this sector tending to engage in a cash business. There were linkages in these responses to the bureaucratic problem that was dominant in the discussion of Question 3.

While the problems with bureaucracy were evident in Questions 3 and 4, the financing problem was paramount in the responses to Question 5. While one interviewee refrained from commenting, all of the other 20 interviewees gave negative comments about access to financing for entrepreneurs. The summary response to this question was a resounding "NO!" Representative responses were in the form of: "difficult to get small business loan/funding", "no interest rate cap for loans", "lack of financing options", "banks focus on SMEs last", "liquidity is an issue", "people don't trust banks", "takes a long time to get financing/two years to get funding", "can't count on banks", "crowdfunding doesn't exist/is illegal", "banks focus too much on collateral", and "different stage funds don't exist/seed stage is no man's land."

Question 6 asked all interviewees whether Tunisian entrepreneurs have the ability to scale their businesses. Fifteen of the interviewees had comments to make here, and all of those comments noted the potential for business success. However, all of the respondents were inclined to say that Tunisian entrepreneurs do not know how to scale their businesses. It was felt that the educational system needed to teach people how to make a good business, not just to start a business. Best management practices were missing, as was training in accounting and finance. Put succinctly by one interviewee, "there needs to be educational reform." Four interviewees pointed to the need for success stories to be better communicated, and the need for role models was also highlighted. In the words of one interviewee, "I want the role model of young kids to be Elon Musk, not a soccer player."

\section{Phase 5 Thematic Insights}

A number of thematic insights emerged from the discourse with Tunisian experts in conjunction with the lit- 
erature. The four themes derived from looking across question responses in the context of the literature provide overall insight about entrepreneurial efforts in frontier markets, not just in Tunisia post-Arab Spring. These four themes are social reform, financing, education, and communication.

Social Reform. As evidenced by the interview data, corruption, lack of transparency, and unnecessary constraints in the bureaucratic process impede entrepreneurial efforts. While recognizing that the development of micro, small, and medium sized enterprises is an imperative for economic growth, the barriers to success are great. Removal of these barriers requires social reform. Unfortunately, the path to social reform continues to be rocky. Wheatley (2019) places the spotlight on the importance of social reform in his commentary on the concerns regarding corruption; for example, in South Africa, overspending in Mexico, and racist, misogynist, and homophobic attitudes in Brazil. Thus, social reform is a key element of economic growth in frontier and emerging markets and that reform has to go hand-in-hand, if not pre-empt, efforts in other areas.

Financing Alternatives. A common thread running throughout all conversations with the Tunisian experts, regardless of the expert's area of interest, was that of financial concerns. Access to financing is a formidable barrier for entrepreneurs. Banks, which are often the traditional financial institutions in frontier and emerging markets, do not understand the needs of start-ups and small/medium-sized businesses. For example, land and property are usually sought-after collateral. Unfortunately, most start-ups and SMEs do not have adequate collateral and banks do not know how to mitigate risks otherwise. Additionally, these banks rely on audited financials in evaluating credit, something start-ups and SMEs tend not to have. Furthermore, the cost and time to complete audited financial statements do not make sense for SMEs in developing economies that must contend with the massively slow, and often corrupt, bureaucracies as noted above. Developing countries where the banking sector is lacking in both competition and the expertise to effectively price loans for SMEs appear ripe for marketplace lending alternatives. Marketplace lenders, since they do not rely on publicly or privately available credit information, work to develop their own methods of credit evaluation specific to the market and situation. Thus, these lenders are better able to support entrepreneurial efforts.

Educational Reformation. Throughout the discussions with Tunisian experts, it became clear that education is key to the growth of SMEs and, thus, economic growth.
Practices must be learned to defy the old ways of doing business, with the young also learning the soft and hard skills necessary to be a successful company manager. Educational reformation will require an investment in people, building a culture of both skill learning and entrepreneurship. Educational reformation can assist in moving businesses from the informal sector to the formal sector, which is where economic growth can be achieved. Emerging market countries have reported a strong growth of students studying in the United States, with Bangladesh, Brazil, Nigeria, and Pakistan showing some of the strongest growth year after year (Institute of International Education, 2019). Unfortunately, the closing of borders in 2020 due to the pandemic will likely depress continued educational advances.

Communication. In an era of information 24/7, it was surprising to hear that there was a lack of communication regarding (1) how to start and scale a business and (2) success stories of individual entrepreneurs or successful SMEs. Theoretically, we know that individuals learn from their environment and from those around them. Thus, it is imperative that emerging and frontier markets make an intense effort to get materials for success into the hands of potential start-up community members. Moreover, creating recognition of those who have been successful with their small and medium sized businesses will feed the entrepreneurial ecosystem and establish role models for others. Of the four major themes derived from this research, communication is the theme largely new to the post-Arab Spring discussion. While the other three major themes have received considerable attention in both scholarly and practice-oriented research, communication has mainly arisen in terms of women and social media use. But, overall, communication as spotlighted by our respondents has not been prominent in the literature.

\section{Conclusion}

While the focus of the current research was Tunisia due to its standing as the sole success story from the Arab Spring, the findings from the interview data should be informative across the spectrum of emerging markets. Two dominant themes emerged in this qualitative research effort. First and foremost, social reforms and financing alternatives are imperative for the development of a culture of entrepreneurship and for the growth of small and medium sized enterprises. Second, to achieve ongoing success in this sector of the economy, there needs to be educational reformation to prepare the next generation (e.g., youth and women) to engage in this formal sector. Accompanying educational reformation, broad 
communication must come in terms of success stories and the role models for others to seek to emulate.

These findings, almost 10 years after the Arab Spring, are likely to not be new information for policy makers. Economic growth has been slow in Tunisia, and the findings from this thematic analysis suggest the problems that have plagued frontier markets continue to resonate in the country. Social reforms have long been an underpinning of the Arab Spring, and concerns continue to arise. While prior research has shown that entrepreneurship, education, and financial reforms are paramount for success, with efforts extended in these two areas, the perceptions of the 21 individuals responding to the queries posed in this research suggest that changes are not occurring as quickly as desired. For social reform to occur, formerly disenfranchised constituents (e.g., women and the young) must not face barriers in terms of financial access, and educational reformation must have a long-term impact in order for the entrepreneurial ecosystem to thrive. Unfortunately, the perceptions of the Tunisian economic experts in our study show numerous concerns that mirror longstanding concerns in many frontier markets.

\section{References}

Alaref, J., Brodmann, S., \& Premand, P. (2019). The medium-term impact of entrepreneurship education on labour market outcomes: Experimental evidence from university graduates in Tunisia. ETH Zurich Research Collection. Retrieved from http://documents1. worldbank.org/curated/en/992711547562372311/pdf/ WPS8701.pdf.

Arieff,A.(2019). Tunisia: In brief. Congressional Research Service, RS2166. Retrieved from https:/crsreports. congress.gov/product/details?prodcode $=\mathrm{RS} 21666$.

Arouri, H., Ben Youssef, A., Quatraro, F., \& Vivarelli, M. (2018). The determinants of young firms' growth in Tunisia (Discussion Papers, No. 11400). Institute of Labour Economics (IZA), Born. Retrieved from http:// ftp.iza.org/dp11400.pdf.

Beck, T. (2013). Bank financing for SMEs - lessons from the literature. National Institute Economic Review, 225(1), R23-R38.

Beninger, S., Ajjan, H., Mostafa, R., \& Crittenden, V. (2016). A road to empowerment: Social media use by women entrepreneurs in Egypt. International Journal of Entrepreneurship and Small Business, 27(2/3), 308-332.

Birch, D. (1987). Job creation in America: How our smallest companies put the most people to work. University of Illinois at Urbana-Champaign's Academy of Entrepreneurial Leadership Historical Research Reference in Entrepreneurship. Retrieved from https://ssrn.com/ abstract $=1496185$.
Bishai, L. \& Mastic, S. (2016). 5 years after the spring. U.S. News \& World Report. Retrieved from https:// www.usnews.com/opinion/blogs/world-report/articles/2016-01-14/5-years-after-tunisias-arab-spring-revolution-challenges-remain.

Carpenter, W. (2020). 3 top frontier markets ETFs. Retrieved from https://www.investopedia.com/articles/ investing/012516/3-best-frontier-markets-indexfunds-fm.asp.

Coleman, S., \& Carsky, M. (1999). Sources of capital for small family-owned businesses. Family Business Review, XII(1), 73-85.

Cravo, T. (2010). SMEs and economic growth in the Brazilian micro-regions. Papers in Regional Science, 89(4), 711-734.

Crittenden, V., \& Crittenden, W. (2010). Strategic management in emerging economies: A research agenda. Organizations and Markets in Emerging Economies, $1(1), 9-23$.

Crittenden, V., \& Crittenden, W. (2012). Corporate governance in emerging economies: Understanding the game. Business Horizons, 55, 567-574.

Crittenden, C., \& Crittenden, W. (2015). The accounting profession's role in corporate governance in frontier markets: A research agenda. Organizations and Markets in Emerging Economies, 5(2), 7-22.

Crittenden, V., Crittenden, W., \& Ajjan, H. (2019). Empowering women micro-entrepreneurs in emerging economies: The role of information communications technology. Journal of Business Research, 98, 191-203.

Dziri, M. H. (2013). Assessing the entrepreneurial ecosystem in Tunisia. Masters Thesis, MIT Sloan School of Management.

Eggers, F. (2020). Masters of disasters? Challenges and opportunities for SMEs in times of crisis. Journal of Business Research, 116, 199-208.

Ettis, S.A., \& Kefi, M.K. (2016). Entrepreneurial intentions amongst Tunisian students: An empirical investigation applying the big-five personality traits theory. International Journal of Higher Education Management, 3(1), 49-64.

Frontier Market News (2020). List of frontier markets and classifications. Retrieved from https://frontiermarketnews.org/list-of-frontier-markets/.

Gabsi, Z. (2019). Tunisia's youth: Awakened identity and challenges post-Arab Spring. British Journal of Middle Eastern Studies, 46(1), 68-87.

García-Quevedo, J., Pellegrino, G., \& Vivarelli, M. (2014). R\&D drivers and age: Are young firms different? Research Policy, 43(9), 1544-1556.

Geller, L. (2017). Why it's time to invest in entrepreneurs in emerging economies. Strategy+Business. Retrieved from https://www.strategy-business.com/article/WhyIts-Time-to-Invest-in-Entrepreneurs-in-EmergingEconomies?gko $=30 \mathrm{~d} 33$. 
Gupta, F. (2011) Developed, emerging, or frontier markets? Journal of Indices. Retrieved from https:// www.etf.com/publications/journalofindexes/joi-articles/9432-developed-emerging-or-frontier-markets. $\mathrm{html}$ ?nopaging $=1$.

Hallberg, K. (2000). A market-oriented strategy for small and medium-scale enterprises. International Finance Corporation, IFD40. Retrieved from http://documents. worldbank.org/curated/en/652031468741329732/pdf/ multi-page.pdf.

Hussain, I., Farooq, Z., \& Akhtar, W. (2012). SMEs development and failure avoidance in developing countries through public private partnership. African Journal of Business Management, 6(4), 1581-1589.

Institute of International Education (2019). Number of international students in the United States hits all-time high. Retrieved from https://www.iie.org/Why-IIE/ Announcements/2019/11/Number-of-InternationalStudents-in-the-United-States-Hits-All-Time-High.

Jamal, A., \& Milner, H. (2019). Economic self-interest, information, and trade policy preferences: Evidence from an experiment in Tunisia. Review of International Political Economy, 26(4), 545-572.

Levisohn, B. (2013). Braving the frontier markets. Retrieved from https://www.barrons.com/articles/SB500 01424052748704372504578290142797535974.

Liberto, D. (2019). Small and mid-size enterprise (SME). Retrieved from https://www.investopedia.com/terms/s/ smallandmidsizeenterprises.asp.

Lotto, J. (2017). Towards the growth of domestic credit in Tanzania: Does foreign capital flow really matter? African Journal of Business Management, 11(7), 140-148.

Masoud, T. (2018). Why Tunisia? Project Muse. Journal of Democracy, 29(4), 166-175.

McCormick, T. (2013). Frontier markets: A short history. Retrieved from https://foreignpolicy.com/2013/03/04/ frontier-markets-a-short-history/.

Minović, J., \& Živković, B. (2010). Open issues in testing liquidity in frontier financial markets: The case of Serbia. Economic Annals, LV(185), 33-62.

Mohti, W. (2019). Essays on frontier markets: Financial integration, financial market efficiency, financial contagion. Unpublished Ph.D. Dissertation, University of Evora, Portugal.

Morched, S., \& Jarboui, A. (2018). Supporting rural entrepreneurship: Role and importance of rural entrepreneurship in Tunisia. International Journal of Management and Development Studies, 7(3), 35-45.

Nowell, L. S., Norris, J. M., White, D. E., \& Moules, N. J. (2017). Thematic analysis: Striving to meet the trustworthiness criteria. International Journal of Qualitative Methods, 16, 1-13.
OCED (n.d.). Small businesses, job creation and growth: Facts, obstacles and best practices. Organisation for Economic Co-operation and Development. Retrieved from https://www.oecd.org/cfe/smes/2090740.pdf.

Osafo-Kwaako, P., Singer, M., White, O., \& Zouaoui, Y. (2018). Mobile money in emerging markets: The business case for financial inclusion. McKinsey \& Company. Retrieved from https://www.mckinsey. com/industries/financial-services/our-insights/mobilemoney-in-emerging-markets-the-business-case-for-financial-inclusion.

O'Sullivan, A., Rey, M., \& Mendez, J. (2011). Opportunities and challenges in the MENA region. Retrieved from https://www.oecd.org/mena/49036903.pdf.

Pellegrino, G., Piva, M., \& Vivarelli, M. (2012). Young firms and innovation: A microeconometric analysis. Structural Change and Economic Dynamics, 23(4), 329-340.

Premand, P., Brodmann, S., Almeida, R. K., Grun, R., \& Barouni, M. (2012). Entrepreneurship training and self-employment among university graduates: Evidence from a randomized trial in Tunisia (IZA Discussion Papers, No. 7079). Institute for the Study of Labour (IZA), Born. Retrieved from https://www. econstor.eu/bitstream/10419/69343/1/733736653.pdf.

Schneider, C., \& Veugelers, R. (2010). On young highly innovative companies: Why they matter and how (not) to policy support them. Industrial and Corporate Change, 19(4), 969-1007.

Shoenholz, D. (2011). The new frontier: Understanding the opportunities, knowing the risks. Retrieved from http://www.ey.com/Publication/vwLUAssets/Frontier_markets/\$FILE/Frontier\%20funds_Final.pdf.

Sidrat, S., Amouri, A., Boujelbene, Y., \& Boudabbous, S. (2016). Entrepreneurship in Tunisia: Obstacles. International Journal of Humanities and Social Science Invention, 5(4), 60-67.

Stereńczak, S., Zaremba, A., \& Umar, Z. (2020). Is there an illiquidity premium in frontier markets? Emerging Markets Review, 42, 1-19.

Touzani, M., Jlassi, F., Maalaoui, A., \& Bel Haj Hassine, R. (2015). Contextual and cultural determinants of entrepreneurship in pre- and post-revolutionary Tunisia: Analysing the discourse of young potential and actual entrepreneurs. Journal of Small Business and Enterprise Development, 22(1), 160-179.

Wheatley, J. (2019). The path to reform looks as rocky as ever for emerging economies. Financial Times. Retrieved from https:/www.ft.com/content/98a6f9304bf1-11e9-bbc9-6917dce3dc62. 